\title{
Place Branding in Web 2.0: the Conceptual Contours of New Generation of Media Policy
}

\author{
Anastasia S. Strekalova \\ Volgograd State University \\ Institute of Management and Regional Economics \\ Volgograd, Russian Federation \\ strekalovaas@mail.ru; sterkalovaas@volsu.ru \\ Google Scholar: Anastasia Strekalova
}

\begin{abstract}
This work proposes a new conceptual framework of media strategies of the place brand that integrates mediology and place branding. This work grounds the importance and timeliness of initiatives in the field of new media policy in Web 2.0 that involve users of social networks as curators, ambassadors, and city-storytellers of the place brand. Examples of initial successful efforts in this area are given.
\end{abstract}

Keywords - place branding, place marketing, journalism about cities, stakeholders, place placement, Web 2.0, media policy

\section{INTRODUCTION}

Quantitative indicators of the global digitalization of modern society allow us to clearly formulate trends. These tendencies should be paid close attention to specialists in the field of territory branding. Examples of trends:

- not slowing over the years, the growth in the number of Internet users;

— increase in digital mobility;

— increase mobile users of social networks;

- the greatest activity in the social networks of users living in developing countries, etc..

According to the forecasts of the authors of the Global Report on the Digital World (Digital in 2017: Global Overview), the total number of mobile media users will only grow [1]. This is also due to the fact that the modern knowledge economy encourages the development of digital freelance professions. Web-based technologies such as blogs and microblogging, wiki projects and social media, photo and video hosting, etc., have become really working marketing tools that can transform the reputation and digital social connections of users into values similar to social capital [2]. These tools need to be transferred to place marketing and place branding in accordance with their specifics and make them integral components of the promotion of place brands in Web 2.0.

The purpose of this work is to initiate a discussion aimed at finding and forming an alternative approach that integrates, within the framework of place branding, two previously isolated concepts - place marketing and modern mediology [3].

\section{MATERIALS AND METHODS (MODEL)}

The research project is based on the integration of the theory and methodology of mediology and place branding. Mediology studies the processes by which a message is sent, circulates, and finds the recipient [3, p. 283], otherwise, these are media studies, which represent a very broad and poorly structured field of knowledge about media and mass communications. These independent approaches, up to the present moment, were practically not used in conjunction. In the theory and practice of place branding, the marketing paradigm dominates, and media studies have little application. And, on the contrary, the media policy of place brands is treated only as one (and not the most important) of the promotion tools. At the same time, of course, the important role of the media is recognized, especially in the place branding and public diplomacy, but no more.

\section{RESULTS AND DISCUSSION}

The conceptual framework traditionally used in place branding is based exclusively on the marketing approach, not taking into account the theory of media communications. As a result, most campaigns in support of place brands focus on advertising and supplementing it with traditional PR-tactics. Although, according to S. Anholt, even a small number of communications between stakeholders based on an adequate and coherent strategy for the development of the place brand will allow for a greater positive effect on the place reputation than a much larger number of impersonal advertising messages [4, p. 10]. At the same time, one-sided advertising of the territory in the media only creates the illusion of respectability of a city or region, demonstrating the availability of "extra" funds in its budget for expensive advertising in traditional media, but does not bring serious results. At the same time, in recent years there has been a growing interest in using social media for marketing and branding, which is associated with an impressive increase in the number of Internet users and an increase in the time spent in social networks. 
TABLE I. DIGITAL WORLD IN 2017

\begin{tabular}{|l|c|c|}
\hline \multicolumn{1}{|c|}{ indicator } & Units & Value \\
\hline Number of mobile device users ${ }^{\text {a }}$ & billion people & 4.92 \\
\hline Number of Internet users & billion people & 3.77 \\
\hline Number of users of social networks & billion people & 2.80 \\
\hline $\begin{array}{l}\text { Number of mobile social networking } \\
\text { users }\end{array}$ & billion people & 2.56 \\
\hline $\begin{array}{l}\text { Growth in the share of mobile phones } \\
\text { in web traffic compared to 2016. }\end{array}$ & $\%$ & 30 \\
\hline $\begin{array}{l}\text { Increase in the number of Internet } \\
\text { users in the world over the past 5 years }\end{array}$ & $\%$ & 80 \\
\hline $\begin{array}{l}\text { The time spent per day in social } \\
\text { networks by the average Russian user }\end{array}$ & hours & 2.19 \\
\hline
\end{tabular}

a. Compiled by the author according to: Digital in 2017: Global Overview. URL: https://wearesocial.com/special-reports/digital-in-2017-global-overview

Place branding is one of the most powerful tools for longterm competitiveness of cities and regions with numerous social effects [4, p. 4-5]. The role of place branding should not be limited to the position on the periphery of marketing and simple scientific curiosity. On the contrary, the symbiosis of the concepts of media policy and place branding in the future can become the driver of a new level of sustainable development of places in the Web 2.0 environment, in an environment where media content is produced primarily by users themselves. Outstanding theorist of network society and post-industrial economy M. Castells describes the current status of media in modern society as a decisive means of communication. The term "media" he denoted a complex of communication organizations, of institutions and technologies, including mass communications, and "mass selfcommunication". Under media policy he meant carrying out a policy in the media, and using the media [5, p. 221].

In the author's interpretation, the media policy of the place brand is the conceptual framework for implementing strategically oriented actions to promote the place brand into the mass consciousness (and subconscious) of target audiences through its controlled reflection in the media space. Media brand policy is viewed as a broader concept compared to the media strategy. The media strategy of place brand is a roadmap that accurately correlates with priorities, imperatives, goals, resources, channels and technologies of communication, timelines and executors, to achieve the desired position of the place brand in the media space.

The growing intensity of Internet communications requires widespread adoption in the classic territorial branding of online tools and new media policies.

M. Florek identifies two of the most promising areas of online place branding, this is to ensure communication around the brand values and identity and to create a cohesive online community associated with the brand [6, p. 113].

Of course, these areas of online place branding is far from being exhausted. But for some reason, scientists, experts and politicians almost accepted a "vow of silence" on this topic. Some studies emphasized the existence of links between place branding and PR policy and strategic communications, but these issues were not studied specifically. Even the leader of modern place branding M. Kavaratzis only raised the issue of the need to study the communicative structure of place brands and the role of journalism about cities in building brand communications, as he considers the key to successful branding the relationship between the brand and its stakeholders [7]. However, his call, voiced back in 2004, was dispersed in the media space without finding further broad development.

Meanwhile, the silence of the theoreticians of place marketing and branding did not prevent practitioners from working in this promising direction. The first pilot projects of targeted media policy of placel brands appeared, for example, in Brussels and Berlin.

The curatorial platform WeLoveBrussels was created in 2014 to spread interest in Brussels and inspire love for this beautiful city. On its basis, local bloggers, digital activists and ordinary citizens can share personal stories about the city (this media tool is called city storytelling). By 2017, \#welovebrussels has been used by more than 50.000 subscribers in various social networks, including Instagram (more than 26.000 people are browsing the project page, more than 1100 photos are posted, receiving an average of 591 likes). On Facebook, the weekly coverage is 37 thousand people, of which more than 10 thousand active users and another 90 thousand people talk about \#welovebrussels in this social network, and every new post receives from 1000 to 6000 views. In addition, \#welovebrussels actively post on Twitter, regularly recruiting from 2000 to 5000 views, with a record tweet scored 27 thousand views. Further plans of the organizers of the curatorial platform include the study and implementation of the best practices of urban journalism, the use of big data technologies, and the use of other digital tools to tell innovative and relevant stories about the city and urban problems in the 21 st century.

Analyzing the Berlin experience of setting up a network of citizens of brand ambassadors, J. Rehmet, K. Dinnie [8] focus on the need to further study the role of such brand ambassadors as a key component of the place branding strategy. The integrated and interactive communication campaign "Berlin", supported by the City Hall, was launched in January 2008 in the presence of more than 350 journalists. In March of the same year, 1.358 thousand letters were sent out announcing a new campaign, the drivers of which were to be the townspeople with their personal success stories connected with Berlin. The center of the campaign is the "be Berlin" portal, which currently consolidates posts on the Facebook page "Berlin - the place to be", which collected $1,663,071$ likes, as well as photos and videos in Instagram with \#beberlin and \#FreiheitBerlin hashtags, 21.276 thousands Twitter subscribers, a video with the topic beBerlin on You Tube video sharing and subscribers in the social network Google+.

Such initiatives in the field of new media policy in Web 2.0 involve the involvement of users of social networks in the role of curators or ambassadors of the place brand. This approach corresponds to modern theoretical views on the perspective of place branding as management of brand relations networks [9], which implies the rejection of a oneway communication model with stakeholders. Such networks, due to the effect "from mouth to mouth" for branding are 
much more effective than advertising. But for their more effective involvement in place branding it is necessary to identify different types of networks, understand how they are managed, determine the motives and expectations of their participants. In the early stages of the network interaction of ambassadors, the network is used by them as a communication device, but over time it "ripens" and consolidates, becoming a promising and economically extremely beneficial resource for the development of place [9]. Therefore, local administrations should recommend using social media more actively not only as duplicative channels for the transfer of official information, but as an instrument for involving the local population in the real processes of territorial changes or at least communications about them; The minimum task is to "make the city speak" [10, p. 7-9].

It is the new (or digital) media, such as interactive electronic publications and multimedia media, that allow the region or city to reach target audiences at any distance from it and engage in constructive dialogue with them. An important advantage of new media is their interactivity, which allows the audience of the territorial brand to get experience of virtual visiting the territory and monitoring the events in real time. At the same time, the shift of territorial branding towards digital initiatives should be connected with the increase of creativity in the selection and creation of the content itself. After the expansion of the audience of information impact increases the risk of incorrect interpretation and retransmission of errors in social networks and blogs, thereby increasing the price of error. P. Kotler noted the trends and opportunities of new media. He said that buyers and other stakeholders are not passive participants in the marketing process. One angry buyer or consumer can put even a successful company under attack [11, p. 153].

This conclusion is also true for the image and place brand. Stakeholders of the territory are not connected, unlike corporate employees, with commercial secrets and ethical codes, besides, it is difficult (more precisely, practically impossible) to apply sanctions to them. In combination with their quantitative advantage (and the number of residents of any, even a small village, obviously exceeds the staff of large companies) and Web 2.0 with technologies that allow generating a huge amount of user content at any time convenient for them, it should be recognized - the time of declarative territory branding irrevocably passed. Such a onesided, formal, isolationist, directive approach to place branding instead of real strategic changes will have a zero and even negative effect, despite even the multimillion-dollar advertising costs in traditional and new media.

Communication from mouth to mouth, reinforced by the media and new media, refers to tertiary communications not controlled by marketers. Texts emitted into media space by official bodies and hired marketing agencies often begin to "live their own lives," and their perception by different audiences is sometimes diametrically opposed to the desired [12]. Consequently, a promising direction for the development of the media policy of territorial brands should be the cultivation of a new type of social activity and a new profession of a journalist of the territory.
The new channels of brand communications of the regions include not only social networks, but also crowdsourcing projects that allow for close interaction and joint production of ideas about the brand of the territory with different target groups. Now the telling of stories about brands of territories is traditionally a function of local authorities or specialized organizations (marketing agencies or media), which leads to the dominance of official and hyper-discourse discourse. It is important to reorient the media policy of the territories' brands to an informal format, for example, by making the main brand creators of local bloggers and activists, and using best practices, for example, the experience of Berlin with the networks of citizens, brand ambassadors, curator network platforms in Brussels, the Amsterdam Festival of Urban Stories and other projects. Another urgent change is the addition of traditional, easily identifiable advertising messages (for example, advertising slogans, brochures, articles, press releases, tourist sites, etc.) with contextual messages (or simply contexts) that are not directly related to advertising. This trend was called embedded marketing. An example is the inclusion of a certain territory in the plot of the film, TV shows and other formats of multimedia content [13]. Thus, the traditional product placement is replaced by a placeplacement. Also, the use of complemented reality technologies and gaming for immersing the user in unobtrusive media content (Second Life, Active Worlds) has significant potential.

Territorial journalism is born before our eyes and constructive work towards the institutionalization of the profession of journalist of the territories is just beginning [14]. And, of course, as journalists and ambassadors of the brand of your city or region, you must maximally involve the inhabitants.

\section{CONCLUSION}

The concept of territorial branding predetermines the basis for managing the region in the most effective way ensuring stability of functioning in the current market conditions, increasing competitiveness, identifying, preventing and preventing negative endo- and exogenous impacts and various threats, adequate forecasting and correct long-term strategic planning, preservation and use of unique characteristics and assets, creating conditions for expanded reproduction of competition governmental benefits for socio-economic development of the region.

But, it is integration into the system of interdisciplinary knowledge of the place branding of modern media sciences (mediology) that will allow to form the conceptual bases of the media policy of the place brand and to present the global role of new social media and concrete forms of influence on mass consciousness through brand communications.

Especially it is necessary to note the important role of professional places journalists who, through activity in social media and various formats of city-story building, can create a critical mass for a positive change in the image of the place brand and even its identity without spending budget funds. From the city and regional authorities, only supportive actions aimed at: 
- creation and support of training programs for the technologies of place journalism, as professional journalists, and bloggers, volunteers, schoolchildren, students, activists, patriots, etc.;

- support for communication platforms for city-planning;

- initiate a discussion about the prospects of Web 2.0 technologies for branding your city or region.

For modern territories that are socially responsible multistakeholder quasi corporations [15], new media technologies and tools should become integral components of the promotion of their places brands in the Web 2.0.

\section{Acknowledgment}

The article was prepared with the support of the Russian Foundation for Basic Research, project № 18-010-00832.

\section{References}

1. Digital in 2017: Global Overview, URL: https://wearesocial.com/specialreports/digital-in-2017-global-overview

2. A. Gandini, "Digital work", Marketing Theory, 2016, vol. 16, iss. 1, pp. 123-141.

3. R. Debray, "Introduction to mediologie" [Vvedenie $\mathrm{v}$ mediologiju]. Moscow: Praksis, 2010, 368 p.

4. S. Anholt, "Editor's foreword to the first issue" Place Branding and Public Diplomacy, 2004, vol. 1, iss. 1, pp. 4-11.

5. M. Castells, "Communication Power" [Vlast' kommunikacii]. Moscow: Higher school of Economics Publ. house, 2016, 564 p.
6. M. Florek, "Online city branding" [Onlajn brending gorodov]. City Branding. Theory and Cases [Brending territorii. Luchshie mirovye praktiki] / Ed. by K. Dinnie. Moscow: Mann, Ivanov and Ferber, 2013, $336 \mathrm{p}$.

7. M. Kavaratzis, "From City Marketing to City Branding: Towards a Theoretical Framework for Developing City Brands", Place Branding and Public Diplomacy, 2004, vol. 1, iss. 1, pp. 58-73.

8. J. Rehmet, K. Dinnie, "Citizen brand ambassadors: Motivations and perceived effects", Journal of Destination Marketing \& Management, 2013, vol. 2, iss. 1, pp. 31-38.

9. M. Andersson, P. Ekman, "Ambassador networks and place branding", Journal of Place Management and Development, 2009, vol. 2, iss. 1, pp. 41-51.

10. Social Media and Local Governments: Theory and Practice / Ed. by M.Z. Sobaci. Springer, 2015, $335 \mathrm{p}$.

11. P. Kotler, The End of capitalism? 14 antidotes against diseases of a market economy [Konec kapitalizma? 14 antidotov ot boleznej rynochnoj jekonomiki]. Moscow: Eksmo, 2016, 288 p.

12. M. Paganoni, City Branding and New Media: Linguistic Perspectives, Discursive Strategies and Multimodality. New York: Palgrave Macmillan, 2015. 162 p.

13. J.M.Wolburg, "Branded Entertainment: Product Placement \& Brand Strategy in the Entertainment Business", Journal of Consumer Marketing, 2008, vol. 25, iss. 1, pp.66-67.

14. D.P. Frolov, "Institutionalization of place marketing (case of representative Russian region)", Montenegrin Journal of Economics, 2013, vol. 9, no. 4, pp. 77-86.

15. D.P. Frolov, A.S. Strekalova, "Place marketing approach to governance of social-ecological clusters", Russia and the European Union. Development and Perspectives. Contributions to Economics. Cham, Switzerland: Springer , 2017, 489 p., pp. 315-319. 